\title{
Formulasi Sediaan Krim Anti Jerawat Ekstrak Etanol Biji Pepaya Muda (Carica papaya L.) Serta Uji Aktivitasnya Terhadap Bakteri Pseudomonas aeruginosaATCC 27825 dan Staphylococcus aureusATCC 25923
}

\section{(Anti Acne Cream Formulation for Young Papaya Seed (Carica papaya L.) Ethanol Extract and Activity Test Against Pseudomonas aeruginosa ATCC 27825 and Staphylococcus aureus ATCC 25923)}

\author{
Nuralifah $^{1}$, Feri Indradewi ${ }^{2}$, Parawansah $^{3}$, Satriana Nasrun ${ }^{2}$ \\ ${ }^{1}$ Bagian Farmakologi, Fakultas Farmasi, Universitas Halu Oleo, Kendari \\ ${ }^{2}$ Bagian Farmasetik, Fakultas Farmasi, Universitas Halu Oleo, Kendari \\ ${ }^{3}$ Bagian Farmakologi, Fakultas Kedokteran, Universitas Halu Oleo, Kendari \\ Corresponding author e-mail: nuralifahapt11@gmail.com
}

\begin{abstract}
Background: Young papaya seeds (Carica papaya L.) contained terpenoids, alkaloids karpain and flavonoids that have been examined has antibacterial activity. Purpose: This study aims to obtain anti-acne cream from extract of young papaya seeds (Carica papaya L.) that possess antibacterial activity against Staphylococcus aureus ATCC 25923 and Pseudomonas aeruginosa ATCC 27825. Methods: Extract of young papaya seeds (Carica papaya L.) was obtained by maceration process using ethanol $96 \%$ and the antibacterial activity of extract conducted by well diffusion method. then the extract formulated into anti acne cream dosage and then tested to characteristic properties including $\mathrm{pH}$ test, dispersive power test, organoleptic test, homogeneity test, viscosity test and irritation test. Result: The results showed anti acne creams of extract young papaya seeds (Carica papaya L.) produced qualified standard and did not cause irritation. Conclusion: Anti acne cream containing extract concentration of 10\% can inhibited bacteria of S. aureus ATCC 25923 with inhibition zone of 17,5 mm and P. aeruginosa ATCC 27825 with inhibition zone of 19,3 mm.
\end{abstract}

Keyword: seeds of papaya (Carica papaya L.), anti acne cream

\section{ABSTRAK}

Latar Belakang: Biji pepaya muda (Carica papaya L) mengandung terpenoid, alkaloid karpain dan flavonoid, yang telah diteliti memiliki aktivitas antibakteri. Tujuan: Penelitian ini bertujuan untuk memperoleh sediaan krim anti jerawat dari ekstrak biji pepaya muda (Carica papaya L) yang memiliki aktivitas anti bakteri terhadap bakteri Staphylococcus aureus ATCC 25923 dan Pseudomonas aureginosa ATCC 27825. Metode: Ekstrak biji pepaya muda (Carica papaya L) diperoleh melalui proses maserasi menggunakan pelarut etanol 96\%, serta uji aktivitas antibakteri ekstrak dilakukan dengan metode sumuran. Ekstrak selanjutnya diformulasikan menjadi sediaan krim anti jerawat dan dilakukan uji karakterisasi meliputi uji pH, uji daya sebar, uji organoleptik, uji homogenitas, uji viskositas dan uji iritasi. Hasil: Hasil pengamatan menunjukkan sediaan krim anti jerawat ekstrak biji pepaya muda (Carica papaya L) yang dihasilkan memenuhi syarat standar nilai $p H$, daya sebar dan viskositas. Hasil uji iritasi memperlihatkan formula krim tidak menimbulkan iritasi. Simpulan: Sediaan krim anti jerawat dengan konsentrasi ekstrak 10\% dapat menghambat bakteri S.aureus ATCC 25923 dengan hambatan sebesar 17,5 mm dan P. aeruginosa ATCC 27825 dengan hambatan sebesar 19,3 $\mathrm{mm}$.

Kata Kunci: biji pepaya muda (Carica papaya L), krim anti jerawat

\section{PENDAHULUAN}

Jerawat (acne vulgaris) adalah salah satu penyakit kulit yang umum ditemukan. Jerawat mempengaruhi daerah kulit yang memiliki banyak folikel sebaceous (kelenjar minyak) seperti wajah, dada bagian atas dan punggung. Jerawat tidak terbatas hanya pada usia remaja. Sebanyak $12 \%$ wanita dan $5 \%$ pria pada usia 25 tahun memiliki masalah jerawat. Menurut Waluyo (2005), jerawat umumnya terjadi pada usia pubertas 10 hingga 17 tahun 
pada wanita, 14 hingga 19 tahun pada pria. Faktor-faktor yang terlibat dalam pembentukan jerawat, diantaranya peningkatan produksi sebum, peluruhan keratinosit, pertumbuhan bakteri, keturunan, hormon, iklim, dan kosmetika. Peradangan pada jerawat yang terinfeksi dapat disebabkan oleh bakteri seperti Pseudomonas aeruginosa dan Staphylococus aureus (Syamsul dkk., 2015).

Sejak dulu, penggunaan bahan-bahan alam sebagai obat telah banyak digunakan di berbagai daerah termasuk Indonesia. Khasiat dari bahan-bahan alam tersebut diketahui berdasarkan pengalaman yang kemudian diwariskan secara turuntemurun. Menurut WHO (World Health Organization) penggunaan obat herbal terus meningkat, baik di negara berkembang maupun di negara-negara maju.

Salah satu tanaman herbal yang banyak digunakan adalah pepaya. Pepaya merupakan salah satu buah yang banyak tumbuh di daerah tropis seperti Indonesia. Pepaya memiliki manfaat yang besar antara lain untuk memperlancar pencernaan, sebagai sumber antioksidan, bahkan mampu berfungsi sebagai antijamur dan antibakteri. Salah satu bagian tanaman pepaya yang memiliki aktivitas antibakteri adalah bijinya.

Diketahui bahwa di dalam biji pepaya yang berwana putih mempunyai potensi sebagai antibakteri pada konsentrasi 1.000 ppm (Martiasih dkk.,2012). Berdasarkan penelitian yang telah dilakukan oleh Okoye (2011), uji aktivitas antibakteri dan antijamur dari ekstrak etanol biji pepaya, diperoleh hasil bahwa biji pepaya muda yang berwarna putih memiliki aktivitas antibakteri terhadap Staphylococcus aureus, Pseudomonas aeruginosa, Salmonella typhi, Eschericia coli dan anti jamur terhadap Asperigllus niger, Penicillium notatum, Fusarium solani, Candida albicans.
Berdasarkan uraian di atas untuk memanfaatkan aktivitas antibakteri ekstrak etanol biji pepaya muda (Carica papaya L.) terhadap bakteri Pseudomonas aeruginosa ATCC 27825 dan Staphylococcus aureus ATCC 25923 maka dibutuhkan sediaan farmasi yang bertahan lama di kulit, salah satunya adalah krim.

Krim merupakan salah satu bentuk sediaan emulsi yang terdiri dari dua tipe yaitu tipe minyak dalam air (M/A) jika minyak terdispersi dalam fase air dan tipe air dalam minyak (A/M) jika air terdispersi dalam fase minyak sebagai pembawa. Emulsi tipe A/M memberikan lapisan yang lebih baik dari pada emulsi tipe M/A karena emulsi tipe A/M mengandung lipid yang lebih besar sehingga kontak dengan kulit lebih lama (Pakki, dkk., 2009). Oleh karena itu, penulis tertarik untuk melakukan penelitian berjudul "Formulasi Sediaan Krim Anti Jerawat Ekstrak Etanol Biji Pepaya Muda (Carica papaya L.) dan Uji Aktivitasnya terhadap Bakteri Pseudomonas aeruginosa ATCC 27825 dan Staphylococcus aureus ATCC 25923” sehingga didapatkan sediaan krim anti jerawat yang dapat memberikan kemampuan menghambat pertumbuhan terhadap bakteri Pseudomonas aeruginosa ATCC 27825 dan Staphylococcus aureus ATCC 25923 yang memiliki potensi untuk dikembangkan pemanfaatannya di bidang kesehatan.

\section{METODE PENELITIAN}

\section{Uji aktivitas antibakteri ekstrak etanol biji pepaya muda terhadap $P$. aeruginosa ATCC 27825 dan S. aureus ATCC 25923}

Bakteri yang diencerkan dengan mencampurkan 1 ose bakteri $S$. aureus ATCC 25923 dan $P$. aeruginosa ATCC 27825 yang telah diremajakan ke dalam tabung reaksi yang telah berisi larutan $\mathrm{NaCl}$ fisiologis $0,9 \%$ untuk membuat suspensi bakteri. Suspensi bakteri dicampurkan ke dalam media NA. Lalu dituangkan kedalam cawan petri yang 
diberi pencadang dan dibiarkan memadat. Dibuka pencadang dan dimasukkan ekstrak biji pepaya muda dengan konsentrasi $1 \%$, 5\% dan $10 \%$ yang telah diencerkan dengan DMSO 10\% dan dimasukkan menggunakan mikropipet ke dalam lubang di media NA. Diinkubasi ke dalam inkubator pada suhu $37^{\circ} \mathrm{C}$ selama 24 jam.

\section{Formulasi krim anti jerawat}

Formulasi krim tipe M/A menggunakan bahan pengemulsi novomer $^{\circledR} 1 \mathrm{~g}$, asam stearat $2 \mathrm{~g}$, metil paraben 0,2 g, propilen glikol $15 \mathrm{~g}$, propil paraben 0,02 g, setil alkohol $2 \mathrm{~g}$, akuades dan ekstrak biji pepaya.

Formulasi krim ekstrak biji pepaya dimulai dengan fase minyak dilebur dengan menggunakan suhu $70^{\circ} \mathrm{C}$, seperti propil paraben, asam stearat, cetyl alcohol, lanolin anhidrat. Kedua, Fase air dibuat dengan melarutkan terlebih dahulu metil paraben dalam air yang telah dipanaskan hingga suhu $70^{\circ} \mathrm{C}$, kemudian ditambahkan propilen glikol. Suhu dipertahankan pada $70^{\circ} \mathrm{C}$. Krim dibuat dengan menuangkan fase minyak ke dalam fase air (dimana suhu masing-masing fase $70^{\circ} \mathrm{C}$ ) sambil diaduk dengan pengaduk elektrik (mixer) secara pengadukan berselang (intermitten shaking: 2 menit pengadukan dengan selang waktu istirahatnya 20 detik). Novomer ${ }^{\circledR}$ dimasukkan, kemudian diaduk kembali. Terakhir, dimasukkan ekstrak biji pepaya dan diaduk hingga terbentuk krim yang homogen. Krim dibuat dengan cara yang sama dengan konsentrasi ekstrak biji pepaya yang berbeda. Rancangan formula krim ekstrak biji pepaya dapat dilihat pada Tabel 1.

\section{Uji aktivitas antibakteri sediaan krim anti jerawat}

Uji daya hambat antibakteri metode sumuran

Bakteri yang diencerkan dengan mencampurkan 1 ose bakteri Staphylococcus aureus ATCC 25923 dan
Pseudomonas aeruginosa ATCC 27825 yang telah diremajakan ke dalam tabung reaksi yang telah berisi larutan $\mathrm{NaCl}$ fisiologis $0,9 \%$ untuk membuat suspensi bakteri. Suspensi bakteri dicampurkan ke dalam media NA. Lalu dituangkan kedalam cawan petri yang telah diberi pencadang dan dibiarkan memadat. Dibuka pencadang dan dimasukkan basis krim tanpa ekstrak (kontrol negatif), formula I, formula II, formula III, dan sediaan X (kontrol positif) menggunakan mikropipet ke dalam lubang di media NA. Diinkubasi ke dalam inkubator pada suhu $37^{\circ} \mathrm{C}$ selama 24 jam.

\section{Evaluasi kestabilan (Cycling test)}

Salah satu cara mempercepat evaluasi kestabilan adalah dengan cycling test. Metode cycling test dilakukan satu siklus pada saat sediaan krim disimpan pada suhu $\pm 4^{\circ} \mathrm{C}$ selama 24 jam lalu dikeluarkan dan ditempatkan pada suhu \pm $40^{\circ} \mathrm{C}$ selama 24 jam. Percobaan ini diulang sebanyak 6 siklus.

\section{Uji Iritasi}

Uji iritasi kulit dilakukan langsung pada manusia dengan cara uji tempel dimana sediaan uji lebih kurang 0,1 g dioleskan pada lengan bagian dalam, kemudiaan ditutup dengan kain kasa. Setelah 24 jam diamati gejala yang timbul. Hasil pembacaan uji tempel bervariasi antara meragukan $(+/-)$, lemah $(+)$, kuat $(++)$, dan hebat $(+++)$ terhadap gejala yang timbul. Pemeriksaan ini dilakukan terhadap 3 orang sukarelawan untuk tiap formula (Ditjen POM, 1985).

Reaksi iritasi positif ditandai oleh adanya kemerahan, gatal-gatal, atau bengkak pada kulit lengan bawah bagian dalam yang diberi perlakuan (Wasita atmadja, 1997).

\section{HASIL}

\section{Skrining Fitokimia}

Skrining fitokimia ekstrak bertujuan untuk mengetahui kandungan senyawa yang terdapat dalam ekstrak etanol biji 
Tabel 1. Rancangan Formula Krim

\begin{tabular}{ccccccc}
\hline \multirow{2}{*}{ No. } & \multirow{2}{*}{ Bahan } & Fungsi & \multicolumn{4}{c}{ Formula krim (\%b/v) } \\
\cline { 4 - 6 } & & & $\mathbf{0}$ & $\mathbf{1}$ & $\mathbf{2}$ & $\mathbf{3}$ \\
\hline 1. & Ekstrak biji pepaya muda & Zat aktif & - & 1 & 5 & 10 \\
2. & Asam stearat & Fase minyak & 2 & 2 & 2 & 2 \\
3. & Setil alcohol & Emolien & 2 & 2 & 2 & 2 \\
4. & Propilen glikol $^{\text {Nonyyyyy}}$ & Humektan & 15 & 15 & 15 & 15 \\
5. & Novomer $^{\circledR}$ & Pengemulsi & 1 & 1 & 1 & 1 \\
6. & Metil paraben & Pengawet & 0,2 & 0,2 & 0,2 & 0,2 \\
7. & Propil paraben & Pengawet & 0,02 & 0,02 & 0,02 & 0,02 \\
8. & Akuades & Fase air & Ad 50 & Ad 50 & Ad 50 & Ad 50 \\
9. & Parfum & Pengaroma & q.s & q.s & q.s & q.s \\
\hline
\end{tabular}

Sumber: Sutritor 2014

Tabel 2. Hasil skrining fitokimia ekstrak etanol biji pepaya (Carica papaya L.)

\begin{tabular}{cc}
\hline \multirow{2}{*}{ Golongan } & Reaksi warna/pengendapan \\
\cline { 2 - 2 } Alkaloid & $(+)$ terbentuknya endapan putih kekuningan \\
Flavonoid & $(+)$ terbentuknya warna merah \\
Tanin & $(+)$ terbentuknya warna hijau kehitaman \\
Saponin & $(+)$ terbentuknya busa selama 15 menit \\
Triterpenoid & $(+)$ terbentuknya warna biru kehitaman \\
\hline
\end{tabular}

Sumber: Data Primer

Tabel 3. Hasil Pengamatan Organoleptis Krim anti jerawat sebelum dan setelah Cycling test

\begin{tabular}{|c|c|c|c|c|c|c|}
\hline \multirow{2}{*}{$\begin{array}{c}\text { Konsentrasi } \\
\text { Ekstrak biji } \\
\text { pepaya muda } \\
\text { (\%) }\end{array}$} & \multicolumn{2}{|c|}{ Warna } & \multicolumn{2}{|c|}{ Bau } & \multicolumn{2}{|c|}{ Konsistensi } \\
\hline & $\begin{array}{l}\text { Sebelum } \\
\text { Cycling test }\end{array}$ & $\begin{array}{c}\text { Setelah } \\
\text { Cycling } \\
\text { test }\end{array}$ & $\begin{array}{l}\text { Sebelum } \\
\text { Cycling test }\end{array}$ & $\begin{array}{c}\text { Setelah } \\
\text { Cycling test }\end{array}$ & $\begin{array}{l}\text { Sebelum } \\
\text { Cycling test }\end{array}$ & $\begin{array}{c}\text { Setelah } \\
\text { Cycling } \\
\text { test }\end{array}$ \\
\hline 0 & Putih & Putih & $\begin{array}{c}\text { Khas } \\
\text { pengaroma }\end{array}$ & $\begin{array}{c}\text { Khas } \\
\text { pengaroma }\end{array}$ & Semi padat & $\begin{array}{l}\text { Semi } \\
\text { padat }\end{array}$ \\
\hline 1 & Cokelat muda & $\begin{array}{l}\text { Cokelat } \\
\text { muda }\end{array}$ & $\begin{array}{c}\text { Khas } \\
\text { pengaroma }\end{array}$ & $\begin{array}{c}\text { Khas } \\
\text { pengaroma }\end{array}$ & Semi padat & $\begin{array}{l}\text { Semi } \\
\text { padat }\end{array}$ \\
\hline 5 & Cokelat tua & $\begin{array}{l}\text { Cokelat } \\
\text { tua }\end{array}$ & $\begin{array}{c}\text { Khas } \\
\text { pengaroma }\end{array}$ & $\begin{array}{c}\text { Khas } \\
\text { pengaroma }\end{array}$ & Semi padat & $\begin{array}{l}\text { Semi } \\
\text { padat }\end{array}$ \\
\hline 10 & $\begin{array}{c}\text { Cokelat sangat } \\
\text { tua }\end{array}$ & $\begin{array}{c}\text { Cokelat } \\
\text { sangat tua }\end{array}$ & $\begin{array}{c}\text { Khas } \\
\text { pengaroma }\end{array}$ & $\begin{array}{c}\text { Khas } \\
\text { pengaroma }\end{array}$ & Semi padat & $\begin{array}{l}\text { Semi } \\
\text { padat }\end{array}$ \\
\hline
\end{tabular}

Sumber: Data Primer

pepaya. Hasil yang diperoleh ditampilkan pada tabel 2.

\section{Pengujian Organoleptis}

Pemeriksaan organoleptis meliputi warna, bau dan konsistensi krim ekstrak etanol biji pepaya muda sebelum dan setelah perlakuan cycling test. Hasil pengamatan organoleptis dapat dilihat pada Tabel 3.

\section{PEMBAHASAN}

Uji aktivitas antibakteri ekstrak biji pepaya muda

Uji aktivitas antibakteri ekstrak etanol biji pepaya muda terhadap bakteri $S$. aureus ATCC 25923 dan P. aeruginosa ATCC 27825 dilakukan dengan menggunakan metode difusi agar untuk mengetahui ada tidaknya aktivitas antibakteri di dalam ekstrak tersebut. Metode difusi dipilih karena pada metode ini ada atau tidaknya pertumbuhan bakteri dapat teramati 
dengan jelas, sehingga dapat memudahkan dalam pengamatan terhadap bakteri uji.

Tabel 4. Hasil pengukuran zona hambat sediaan krim anti jerawat ekstrak biji pepaya muda (Carica papaya) terhadap bakteri $S$. aureus ATCC 25923 dan P. aeruginosa ATCC 27825

\begin{tabular}{cccc}
\hline Bakteri & $\begin{array}{c}\text { Konsentrasi } \\
(\mathbf{\%})\end{array}$ & $\begin{array}{c}\text { Diameter } \\
\text { Daerah } \\
\text { Hambat } \\
(\mathbf{m m})\end{array}$ & Interpretasi \\
\hline \multirow{5}{*}{ S. aureus } & 1 & 11,9 & Kuat \\
& 5 & 15,4 & Kuat \\
& $\mathrm{K}(+)$ & 17,5 & Kuat \\
& $\mathrm{K}(-)$ & 10,3 & Kuat \\
& 1 & 13,4 & - \\
P. & 5 & 15,9 & Kuat \\
aeruginosa & 10 & 19,3 & Kuat \\
& $\mathrm{K}(+)$ & 11,8 & Kuat \\
& $\mathrm{K}(-)$ & 0 & - \\
\hline
\end{tabular}

Sumber: Data Primer

Pengujian aktifitas antibakteri yang dilakukan terhadap bakteri $S$. aureus ATCC 25923 dan P. aeruginosa ATCC 27825 menunjukkan daya antibakteri dalam rentang 15,3 - 19,9 mm termasuk kedalam kategori aktivitas kuat. Aktivitas antibakteri yang kuat pada biji pepaya muda disebabkan karena komponen kimia yang terdapat dalam ekstrak biji pepaya muda menunjukkan terdapat senyawa bioaktif seperti alkaloid, flavonoid, saponin, triterpenoid dan tanin.

\section{Formulasi krim anti jerawat}

Formulasi sediaan krim anti jerawat merupakan sediaan krim yang digunakan untuk mencegah terjadinya jerawat. Krim anti jerawat dibuat menggunakan tiga konsentrasi ekstrak yang berbeda yaitu $1 \%$, 5\%,dan $10 \%$.Krim anti jerawat yang diformulasikan ini terdiri dari ekstrak biji pepaya sebagai zat aktif, Asam stearat (basis), Setil alkohol (emolien), Propilen glikol (Humektan), Novomer ${ }^{\circledR}$ (pengemulsi), Metilparaben (pengawet), Propilparaben (pengawet), Akuades (Pelarut). Bahan-bahan yang digunakan sesuai dengan ketentuan yang digunakan dalam pembuatan sediaan krim.

Pada krim anti jerawat ekstrak etanol biji pepaya muda yang dibuat dipilih Asam stearat dalam sediaan topikal digunakan sebagai emulgator atau zat pengemulsi dan solubilizing agent (Armstrong, 2006). Pada krim tipe M/A adanya asam stearat dapat menyebabkan krim menjadi lebih lunak sehingga viskositasnya semakin rendah. Jenis basis yang mempunyai viskositas tinggi akan menyebabkan koefisien difusi suatu obat dalam basis menjadi rendah, sehingga pelepasan obat dari basis akan kecil (Lachman dkk., 1989). Etil alkohol dapat meningkatkan konsistensi emulsi W/O dengan konsentrasi 2-10\%, dan meningkatkan stabilitas sediaan semisolid. Sedangkan Novomer ${ }^{\circledR}$ dipilih karena mempunyai kelebihan yaitu dapat diformulasikan pada suhu rendah, dapat mempertahankan kualitas produk dibawah kondisi penyimpanandipercepat, stabil pada emulsi yang mengandung bahan aktif berupa elektrolit, dapat mensuspensikan bahan seperti zink oksida, memberikan rasa lembut pada kulit, emulsifikasi yang singkat, dan efisien pada konsentrasi rendah.

\section{Uji aktivitas antibakteri sediaan krim anti jerawat}

Pengujian aktivitas ini dilakukan dengan cara uji difusi sumuran, yang dibuat dalam 3 konsentrasi yaitu $1 \%, 5 \%$, $10 \%$, basis krim (control (-), dan sediaan X (kontrol $(+)$. Diharapkan dalam pengujian daya hambat ini yang bersifat sebagai antibakteri adalah ekstrak biji pepaya. Kemudian dilakukan inkubasi pada suhu pertumbuhan optimum S. aureus ATCC 25923 dan P. aeruginosa ATCC 27825 yaitu $37^{\circ} \mathrm{C}$ selama 24 jam. Dari hasil pengujian yang dilakukan menunjukkan bahwa semua konsentrasi menunjukkan ekstrak biji pepaya memiliki daya penghambatan terhadap pertumbuhan $S$. aureus ATCC 25923 dan P. aeruginosa ATCC 27825. Daya penghambatan ini 
ditunjukkan dengan adanya zona bening (zona hambat) disekitar sumuran (Gambar 1).

Hasil pengukuran zona hambat sediaan krim anti jerawat biji pepaya muda disajikan pada Tabel 4. Berdasarkan Tabel ini dapat diketahui bahwa zona hambat yang terbentuk akan meningkat dengan bertambahnya konsentrasi ekstrak biji pepaya yang diberikan dan memiliki respon penghambatan terhadap pertumbuhan bakteri $S$. aureus ATCC 25923 dan $P$. aeruginosa ATCC 27825 karena memiliki ukuran zona bening 11,9 $\mathrm{mm}, 15,4 \mathrm{~mm}, 17,5 \mathrm{~mm}$ dan kontrol $\left(^{+}\right)$ $10,3 \mathrm{~mm}$ pada bakteri $S$. aureus ATCC 25923, dan ukuran zona bening 13,4 mm, 15,9 mm, 19,3 mm dan kontrol (+) 11,8 mm pada bakteri $P$. aeruginosa ATCC 27825.
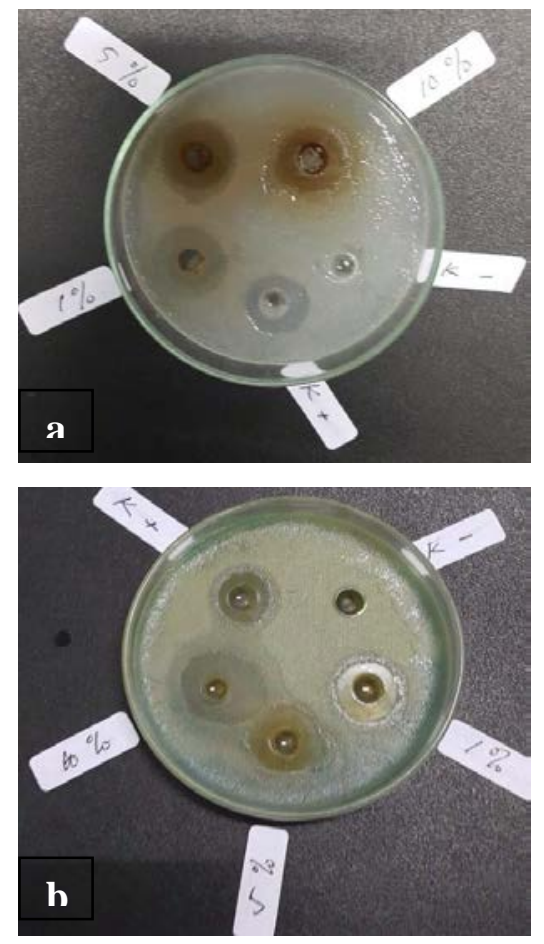

Gambar 1. Zona hambat sediaan krim anti jerawat ekstrak etanol biji pepaya muda terhadap bakteri S.aureus ATCC 25923 (a) dan P.aeruginosa ATCC 27825 (b)

Pada tabel 4 juga terlihat bahwa terjadi penurunan daya hambat bakteri setelah diformulasi. Hal ini dapat dikorelasikan dengan viskositas krim, semakin besar viskositas maka akan semakin besar pula tahanannya sehingga menghalangi pelepasan zat aktif akibatnya penghambatan terhadap bakteri menjadi menurun (Jaelani, 2012). Sedangkan untuk kontrol (-) (basis krim tanpa ekstrak) yang digunakan tidak terdapat hambatan baik pada perlakuan pertama, maupun kedua.

Untuk kontrol negatif menunjukkan bahwa basis krim tidak mempunyai zona hambat, sehingga basis krim tidak mempunyai aktivitas antibakteri terhadap S. aureus ATCC 25923 dan P. aeruginosa ATCC 27825. Kontrol positif bertujuan untuk melihat gambaran terbunuhnya bakteri uji yang dilihat dari zona bening. Sedangkan kontrol negatif bertujuan untuk membuktikan bahwa basis krim y ang digunakan tidak mempunyai aktivitas terhadap bakteri uji.

Kontrol (+) Sediaan X yang yang mengandung bahan bio aktif $\alpha$-Terpineol $1 \%$ yang berfungsi sebagai antimikroba memiliki ukuran zona bening $10,3 \mathrm{~mm}$ pada bakteri S. aureus ATCC 25923 dan $11,8 \mathrm{~mm}$ pada bakteri $P$. aeruginosa ATCC 27825, pada sediaan krim konsentrasi 1\% dan kontrol positif (bio aktif $\alpha$-Terpineol 1\%) tidak mempunyai perbedaan yang signifikan. Hal ini menunjukan pada sediaan krim ekstrak biji pepaya muda konsentrasi $1 \%$ dan bio aktif $\alpha$-Terpineol $1 \%$ memiliki keefektifan yang sama dalam menghambat $S$. aureus ATCC 25923dan P.aeruginosa ATCC 27825, sediaan $\mathrm{X}$ mengandung bio aktif $\alpha$ Terpineol 1\% merupakan krim anti jerawat yang sudah dipasarkan yang memiliki kemampuan menghambat bakteri. Sediaan krim ekstrak biji pepaya muda dengan konsentrasi $1 \%$ yang mempunyai keefektifan sama dengan sediaan $\mathrm{X}$ mengandung bio aktif $\alpha$-Terpineol $1 \%$ sehingga sediaan krim ekstrak biji pepaya muda mempunyai potensi untuk dikembangkan sebagai krim anti jerawat. Hasil yang didapat menunjukkan bahwa sediaan krim ekstrak biji pepaya muda memiliki respon penghambatan yang kuat terhadap pertumbuhan bakteri $S$. aureus 
ATCC 25923 dan P. aeruginosa ATCC 27825. Dengan demikian, hasil dari pengujian tersebut menunjukkan setiap konsentrasi dari masing-masing sediaan krim ekstrak biji pepaya muda memberikan zona hambat yang berbeda yang semakin besar konsentrasi ekstrak semakin besar pula zona hambat yang terbentuk. Pengawet yang digunakan yaitu metil paraben dan propil paraben, digunakan dalam bentuk kombinasi karena dapat meningkatkan efeknya terhadap bakteri dan jamur (Rowe dkk., 2009).

Perbedaan besarnya zona hambat yang terbentuk pada masing-masing konsentrasi dapat diakibatkan karena adanya perbedaan besar kecilnya konsentrasi atau banyak sedikitnya kandungan zat aktif antibakteri yang terkandung di dalamnya, serta kecepatan difusi bahan antibakteri kedalam medium agar.

Faktor-faktor lain yang juga
dianggap dapat mempengaruhi
terbentuknya zona hambat adalah
kepekaan pertumbuhan antibakteri, reaksi
antara bahan aktif dengan medium dan
temperatur inkubasi. Terbentuknya zona
bening merupakan bentuk penghambatan
pertumbuhan terhadap S. aureus ATCC
25923 dan P. aeruginosa ATCC 27825.

\section{SIMPULAN}

Berdasarkan hasil penelitian maka dapat disimpulkan ekstrak etanol biji pepaya muda memiliki kandungan senyawa golongan alkaloid, flavonoid, terpenoid, saponin dan tanin. Ekstrak etanol biji pepaya muda dengan konsentrasi 1\%, 5\% dan 10\% dapat menghambat bakteri Staphylococcus aureus ATCC 25923 dengan nilai 15,3 mm, 16,3 mm, 19,3 mm dan Pseudomonas aeruginosa ATCC 27825 dengan nilai $16,4 \mathrm{~mm}, 17,9 \mathrm{~mm}, 19,9 \mathrm{~mm}$. Ekstrak etanol biji pepaya muda dapat diformulasikan dalam bentuk sediaan krim anti jerawat dengan konsentrasi 1\%, 5\% dan 10\%. Ekstrak etanol biji pepaya muda dengan konsentrasi 1\%, 5\%, 10\% dapat diformulasikan menjadi krim anti jerawat yang memiliki aktivitas antibakteri terhadap bakteri Staphylococcus aureus ATCC 25923 dengan nilai 11,9 mm, 15,4 $\mathrm{mm}, \quad 17,5 \mathrm{~mm}$ dan Pseudomonas aeruginosa ATCC 27825 dengan nilai 13,4 mm, 15,9 mm, 19,3 mm.

\section{SARAN}

Perlu dilakukan dengan menggunakan pelarut yang lain untuk melihat sensitivitas pada aktivitas antibakteri penyebab jerawat.

\section{DAFTAR PUSTAKA}

Armstrong, M., 2006, A Handbook Human Resource Management Practice $10^{\text {th }}$ Edition, Kogan Page, London.

Ditjen POM, 1985, Formularium Kosmetika Indonesia, Departemen Kesehatan Republik Indonesia, Jakarta.

Lachman, L., 1989, Teori dan Praktek Farmasi Industri, UI Press, Jakarta.

Martiasih, M., Boy, R. S., Kianto A., 2012, Aktivitas Antibakteri Ekstrak Biji Pepaya Terhadap Escherichia coli dan Streptococcus pyogenes. Fakultas Teknobiologi Universitas Atma Jaya Yogyakarta.

Okoye, E.I, 2011, Preliminary Phytochemical Analysis And Antimicrobial Activity Of Seeds Of Carica Papaya, Journal of Basic Physical Research, 2 (1).

Pakki, E., Syaharuddin K., Muzakkir R. dan Sony K., 2009, Uji Aktivitas Antibakteri Enzim Papain Dalam Sediaan Krim Terhadap Staphylococcus aureus. Jurnal Majalah Farmasi Dan Farmakologi. 13(1). 1

Rowe, R. C., Sheskey, P. J., Quinn, M. E., 2009, Handbook of Pharmaceutical Excipients, Pharmaceutical Press dan The American Pharmacists Association, USA.

Syamsul, E. S., Supomo, Heri, W., dan Bramantyo, A. N., 2015, Formulasi Ekstrak Etanol Umbi Bawang 
Tiwai (Eleutherine americana) Dalam Sediaan Krim Anti Acne, Traditional Medicine Journal, 20(3), 149-150.

Waluyo, L., 2005, Mikrobiologi Umum, Cetakan Ke- 2, UMM Press, Malang.
Wasitaatmadja, S. M., 1997, Penuntun Ilmu Kosmetik Medik. Penerbit UIPress. Jakarta. 